\title{
SÁNDOR RADNÓTI* \\ BEING AND NOTHING \\ CASPAR DAVID FRIEDRICH: THE MONK BY THE SEA
}

\begin{abstract}
The Monk by the Sea stands alone in the œuvre of Caspar David Friedrich. Unlike the majority of his works, which are generally overburdened with meaning, making them easy to understand from a Romantic, Christian or nationalist perspective, this painting remained resistant to interpretation by almost all of his contemporaries - even by the artist himself - because the reduction and "minimalism" in the work was so unprecedented and extreme that it would take several generations before it became common practice. This was also the first work to feature Friedrich's famous innovation, the Rückenfigur, the picture's internal spectator, who forms a close and subjective bond with the external spectator, while the subject of the spectacle itself, for the very first time in the history of painting, is "nothing".

Keywords: landscape, seascape, Caspar David Friedrich: Monk by the Sea, minimalism, accidental masterpiece, Heinrich von Kleist, Clemens Brentano, Friedrich Schleiermacher, "Rückenfigur", staffage figures, Jan van Eyck, turning nothingness into landscape, anxiety
\end{abstract}

(T)he poet is a light and winged and holy thing, and there is no invention in him until he has been inspired and is out of his senses, and the mind is no longer in him... God takes away the minds of poets, and uses them as his ministers..., in order that we who hear them may know them to be speaking not of themselves who utter these priceless words in a state of unconsciousness, but that God himself is the speaker, and that through them he is conversing with us. And Tynnichus the Chalcidian affords a striking instance of what I am saying: he wrote nothing that any one would care to remember but the famous paean which; in every one's mouth, one of the finest poems ever written...

These lines of Plato are from his early dialogue, Ion. ${ }^{1}$ This classical theory of divine inspiration was not a

\footnotetext{
* Sándor Radnóti, professor emeritus, Institute for Theory of Art and Media Studies, Department of Aesthetics, Eötvös Loránd University, Budapest, Hungary; e-mail: sradnoti@ gmail.com
}

world away from Romanticism, ${ }^{2}$ and if Caspar David Friedrich was aware of it, it may have nourished his religious devotion, with its pietistic hues, as well as his profound suspicions about the conceptual knowledge of an artwork. Yet it is not because of this aspect of the artist that it crossed my mind, but something far more risky: namely, because of all the paintings in Friedrich's œuvre, the one that stands alone is the seascape painted between 1808 and 1810, commonly referred to as The Monk by the Sea (Fig. 1). "Perhaps the most radical and most memorable of all his images". 4 We could even go so far as to say that it is a painting almost without continuation. Whilst from today's perspective it appears that this work was almost a century ahead of his time, this may have been the reason why it remained unfollowed, its authorial interpretation was cheapened by the banality of its pendant, and Friedrich found his way back to the work over the course of his later career only on rare occasions. However, we would be hard put to find a worse piece of advice than that offered by William Vaughan, whose words were just quoted above, who went on to say that, "despite 


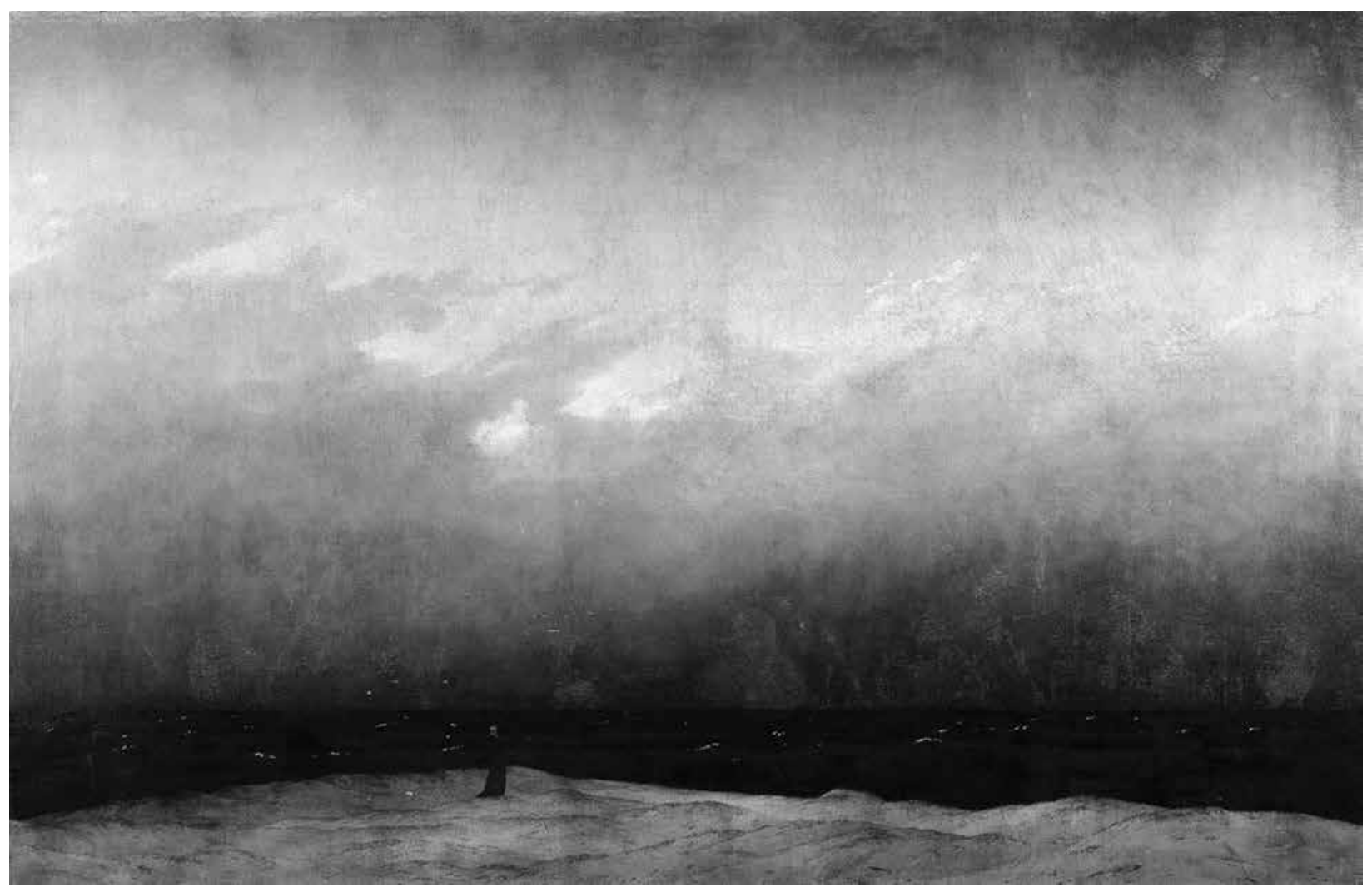

Fig. 1. Caspar David Friedrich: The Monk by the Sea, 1808-1810; Alte Nationalgalerie, Staatliche Museen zu Berlin (photo: Miklós Szüts)

its revolutionary appearance, this picture should not be interpreted out of context" ${ }^{5}$ This, however, is the very thing that I intend to do below.

I describe the reference I made above as "risky" because it professes about a painter who has been uninterruptedly revered and admired since the beginning of the twentieth century that, despite his exceptional skill at drawing landscapes, his talent for evoking atmosphere, his intense working method, his compositional consistency, his inventions, and his generally praiseworthy tendency to look upon life with gloomy seriousness, a substantial part of his output is vulnerable to accusations of being what we would now call - or what eventually became - kitsch. Such famous paintings fall into this category, in my opinion, as The Cross in the Mountains (The Tetschen Altar) (1808), which launched the most successful decade of Friedrich's career, Morning in the Riesengebirge (1810), the pendants entitled Winter Landscape and Winter Landscape with Church (1811), The Wanderer above the Mists (1818; Fig. 2), Chalk Cliffs on Rügen (1818), Two Men Contemplating the Moon (1819), The Sea of Ice (1823/24), The Stages of Life (1835), and so on. It is only within a theory of kitsch that I am able to attempt to justify and substantiate my provocative assertion, although I hasten to state that in no way can we include among such works his less popular but nevertheless highly acclaimed late masterpiece, The Grosse Gehege near Dresden (1832), ${ }^{6}$ or the remarkable, though less frequently discussed pair of paintings that share the title Evening (1824, Mannheim and Vienna), which, at approximately one sixth of the size, are reminiscent of the "Monk", or the similarly diminutive Ship on the Elbe in the Early Morning Fog in Cologne, from the early 1820s, and the list could go on.

Friedrich's works are customarily interpreted in three ways, often in combination with one another: as documents of Christian spirituality, as political statements, and as expressions of early Romantic - melancholic, natural mystic - yearning. Accordingly, he is regarded as a religious, nationalist, and/or Romantic painter. Werner Busch, author of an outstanding modern work on Friedrich, ${ }^{7}$ excoriated these usually iconographic attributions of meaning, and targeted their dismantlement - "Entikonographisierung", as he called it. One thing he failed to address, however, was what makes Friedrich's paintings so susceptible to having their symbols read, in a way which is often unavoidable; I find myself doing so when I see crosses in the middle of uninhabited mountains or forests (his 
innovation of the landscape-cross), or figures meditatively contemplating nature who are dressed in clothes that flout the official ban on Old German costume at the time.

It is inevitable that we will ascertain a certain overload of meaning in numerous works by Friedrich, even as we acknowledge Busch's endeavours to seek traces of the aesthetic articulation and resolution of religious and political meaning within them, as opposed to the obligatory orthodox iconography, understood as a pictorial language. ${ }^{8}$ Indeed, the painter strictly observed several personally tailored formal rules (golden section, hyperbola, etc.). The question is, though, whether or not a significant number of his works contain, side by side, some kind of arbitrary, idiosyncratic language of form and symbology of meaning. If so, then the iconographic interpretations by the supreme Friedrich specialist, Helmut Börsch-Supan, which often appear as unsurpassably mechanistic symbolic construals (the approaching ship, for instance, is one of several symbols that are always, in Börsch-Supan's view, a memento mori; indistinct formations in the distance are promises of the afterlife, the anchor offers hope of resurrection, and the rising moon or crescent is a symbol of the Redeemer ${ }^{9}$ ), would at least comply with Friedrich's intent.

Conversely, it would not be contradictory to wonder, if he were bound by a kind of compulsory iconographic dictionary, then...

why does Friedrich not continue the pictorial language of the Baroque, with all its compositional conventions? Why does he tell no stories? Why does he not paint Christ on the Cross on Golgotha, but rather a metal crucifix up in the mountains - what is more, one that turns away from us -, as in the Tetschen Altar? Why are the churches in his pictures often such ruins? Why do his figures so frequently turn away from us? ${ }^{10}$

It is possible, of course, from a critical point of view, to reply that Friedrich perhaps wanted to build a new vocabulary on the ancient ruins he depicted in his paintings, and that he experimented with a pictorial language which was connected to religious and, in part, political renewal, or at least to such a hope, but which in fact necessarily sheltered individual meaning. The tradition into which he assimilated was not narrative painting, but landscape painting, which had already undergone a certain aesthetic transformation in the mid-seventeenth century, with the expansion

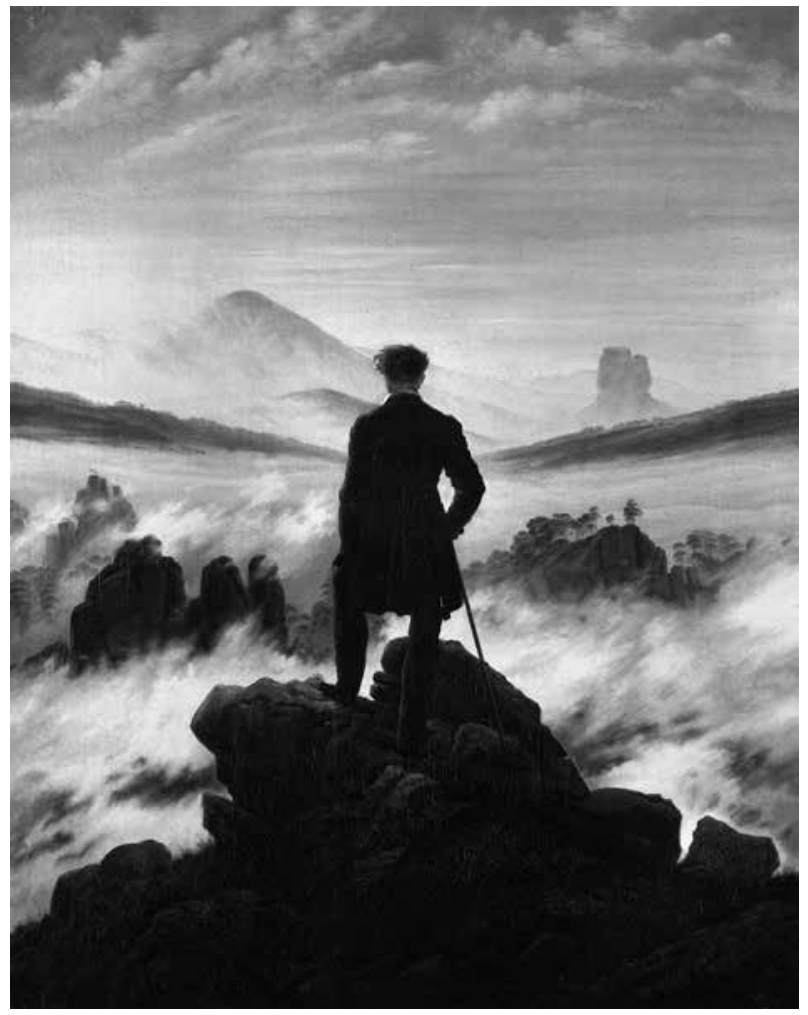

Fig. 2. Caspar David Friedrich:

The Wanderer above the Mists, 1818; Hamburger Kunsthalle

and trivialisation of the theme, and the lessening of iconographic meaning. Friedrich was greatly influenced by Claude Lorrain, ${ }^{11}$ but not in this sense: he burdened his landscapes with earnest but uncomplicated religious, political and personal-subjective sentiments. The paucity of his motifs and their constant reiteration facilitate an interpretation which assumes that Friedrich intended a large part of his works to be exempla that could be easily read, with unambiguous meanings - bringing about every attendant paradox and problematic aspect of modernity.

When it comes to the painting entitled The Monk by the Sea (Fig. 1), however, all of these statements are untrue, or - to phrase things more cautiously - they can only be "inferred" from this context. This particular painting has been researched with extraordinary thoroughness in the literature, so I need not experiment with an investigative study, as I did with the lesser known work by Claude Lorrain titled An Old Man on the Sea Shore. ${ }^{12}$ One of the crucial realisations in the literature is that during the process of creation, the painting went through four distinct stages (which can be reconstructed using contemporaneous documents, such as descriptions of the work by visitors to his studio, as well as modern X-ray and infrared reflectography imaging $^{13}$ ), each involving fundamental changes, which 
always led in the direction of major formal and substantive reduction. The ships, which play a symbolic or allegorical role in his ceuvre, were removed from both the left and the right halves of the painting; the celestial bodies disappeared from the firmament, which was changed from calm to distressed, making it impossible to determine the time of day; the boundary between sea and sky was also deliberately blurred. The exceptionally low horizon is uncertain, because it can also be conceived as a darker-coloured strip of the sea. Apart from the tiny figure, the only living creatures are the gulls, and even their outlines can be confused with the crests of the waves - as though we were looking at a work by Maurits Cornelis Escher. This further contributes to the relativisation of the skyline. (The same painterly concetto is continued in the pendant to this work, where the monks could be mistaken for gravestones.)

In Friedrich's works the naturalism in his details does not connect with the realism of location (even the famous chalk cliffs of Rügen cannot be found in reality in the same way as he painted them), but he tended to copy details with meticulous - we could even say reverential - accuracy from on-site drawings and portraits of trees that he had made earlier, sometimes even decades earlier. In the case of the "Monk", a drawing that Friedrich made in Rügen in 1801 has been found, whose coastline was precisely followed in the painting, and this has enabled Werner Busch to pinpoint the location. ${ }^{14}$ But here too, the interesting thing is his reduction: except for the exactitude in the line of the dune, which could only be revealed through research, the picture destroys all means of topographical identification (not counting, for example, such generalities as the fact that the landscape is from the northern and not the southern hemisphere). The drawings of the Rügen seascape that he made in 1801 - which already carry the promise of a diligent, refined and contemplative minor master - feature objects (ships, bollards, nets drying on sticks on the shore, etc.) that would reappear regularly in his paintings over the subsequent decades, but here there is no trace of them, or more precisely, there is only a trace of them, because they were later removed.

Friedrich's own description of the painting came to light in 1987:

To wit, it is a seascape. First comes a barren sandy beach, then the unsettled sea, and then the air. Along the beach walks a man in a black cloak, deep in thought; seagulls hover around him, shrieking anxiously, as if to warn him not to venture into the tempestuous waters. ${ }^{15}$
I suspect that Friedrich did not quite realise what he had created with this painting. His constant reworkings of the picture were only interrupted by the approaching deadline of the exhibition in Berlin, and it was with reluctance - and delay - that he dispatched the work, which turned out to be the greatest success of his life. The year, or perhaps even two years, that he spent working on this painting imply uncertainty and doubt. Yet the point I am trying to arrive at here is that his description of the work features a glaring omission. He does not refer to the figure as a monk.

It is for this reason that I place inverted commas around the conventional title of the painting. None of the studio reports written at the various stages of production mentions a monk either. ${ }^{16}$ The first description of the figure (Fig. 3) as a Capuchin friar was made, without any justification at all, in the famous, ecstatic text about the painting written by Heinrich von Kleist and Clemens Brentano, published in the 13 October 1810 issue of the Berliner Abendblätter, of which Kleist was editor. ${ }^{17}$ Truth be told, such an identification is not completely without justification, partly because the black gown (schwarzes Gewand) worn by the figure in the picture, as referred to by Friedrich, could be regarded as a monk's habit - although the habit

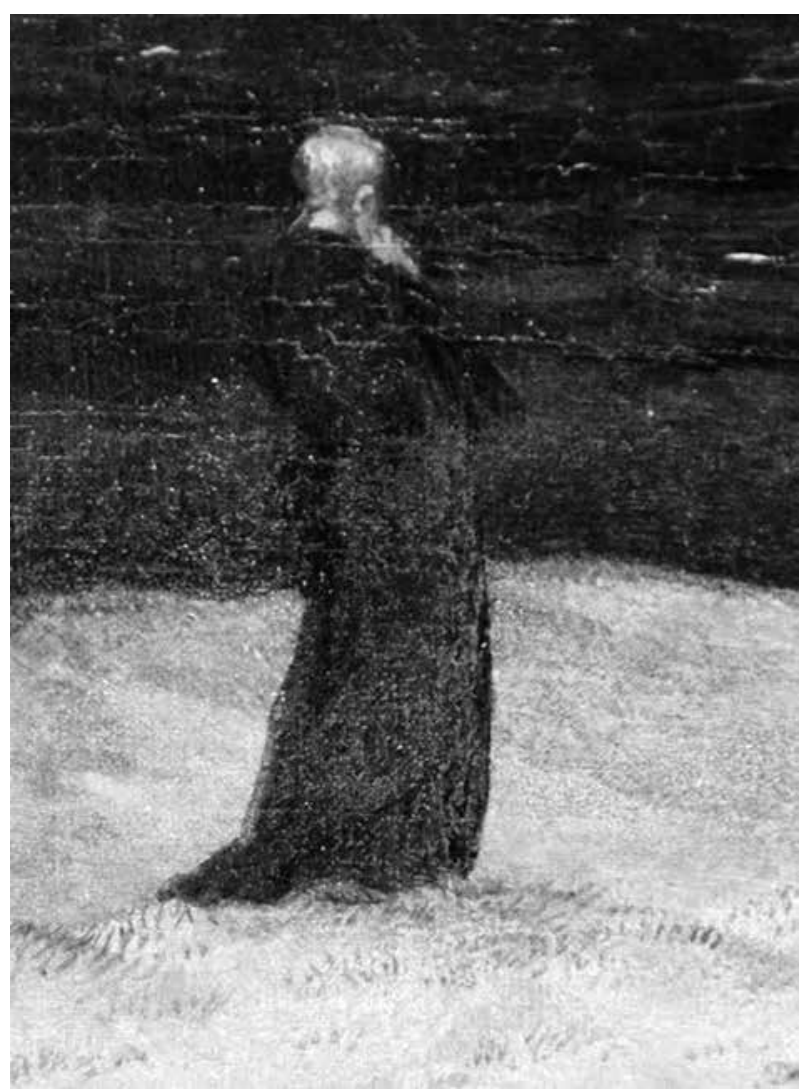

Fig. 3. Caspar David Friedrich: The Monk by the Sea, detail 
worn by the Franciscan Capuchins happens to be dark brown (which, incidentally, is the colour that I can see in the painting). Moreover, the figure is barefoot (Fig. 4), a familiar form of behaviour in monastic asceticism. Apart from the picture, however, consideration should also be given to its pendant, The Abbey in the Oakwood, which shows a group of monks filing after a coffin into a ruined church. Börsch-Supan has

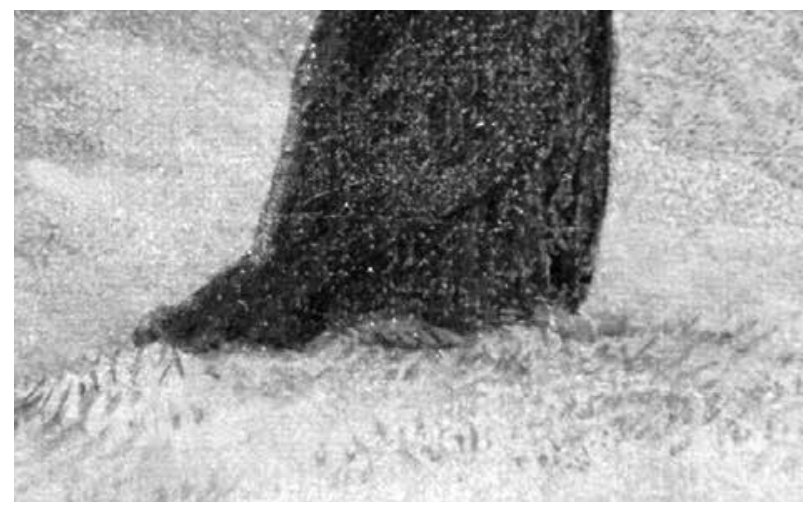

Fig. 4. Caspar David Friedrich: The Monk by the Sea, detail

suggested that the "monk" is also a self-portrait of the artist (a possibility raised by the figure's saffron-coloured hair). He further proposes - also, unfortunately, a not unreasonable possibility - that the pendant is a celebration of the artist's own death, ${ }^{18}$ and since the monks are certainly burying one of their own at this funeral, this would confirm that in the other painting he portrayed himself by the sea as a monk.

The concept of the pendant, borrowed from Claude Lorrain, became fraught with problems when tackled by Friedrich, for unlike Claude, who limited the scope of his contrasts to time of day and lighting, Friedrich attempted to force a story on his otherwise radically contemplative and resolutely non-narrative paintings. One dispiriting example of this is the pair of Winter Landscapes of 1811, now in Schwerin and London (a variation of the second in Dortmund), one of which shows a man on crutches, apparently lost in the snow, while the other features the abandoned crutches (!) in the foreground, the man resting against the rock of faith, praying to Christ on the Cross in front of a pine tree, and a vision of a Gothic cathedral rising out of the haze in the distance, echoing the outline of the tree. If placed alongside its own pendant, the "Monk" would be similarly banalised by the resultant narrative, with its religio-melodramatic investiture of death as the redemptive promise of a life gone astray.

An explanation can also be found for why the monks entering the ruins of the Cistercian abbey church here, and who otherwise appear so often in Friedrich's paintings, are Capuchin friars. As Busch reasons, there may be a political meaning at play, for in the early nineteenth century the hooded monks were among the most impassioned and dedicated enemies of Napoleon. ${ }^{19}$

All this, however, entirely contradicts the fundamental reduction that is so much the essence of the seascape. It is possible that Friedrich had such considerations, or that such considerations were among his intentions, but in the picture we see something different. After all, when the artist turns from describing the picture to enlarging on his thoughts, what we read is a remarkably vacuous and nugatory predication:

You may ponder from morning till evening, and
from evening till darkest midnight, still would you
neither conceive nor comprehend the unfathom-
able Hereafter!
With wanton arrogance, you imagine yourself
becoming a light to posterity, illumining the dark-
ness of the future! This is no more than holy retri-
bution, visible and cognisable only through faith;
and finally [you imagine yourself] knowing and
understanding clearly!
Though your footsteps sink deep in the deserted
sandy beach, yet a gentle wind blows over them,
and your tracks are no longer to be seen: foolish
person, full of nought but conceited pride!

These platitudes, though honestly laying bare his genuine faith, could not have been responsible for summoning up the unparalleled popular, social, commercial and intellectual success that the painting enjoyed in Berlin in 1810. More than any other work at the exhibition, this one truly caught the attention of visitors, naturally with mixed emotions. This work and its pendant were bought by the king, at the insistence of his teenage son, the heir to the throne and future Friedrich Wilhelm IV. The leading figures of early Romanticism, Achim von Arnim and Clemens Brentano, together penned an article about it; Heinrich von Kleist took an excerpt from Brentano's contribution to this article and supplemented it with words of his own, which he then published in the periodical he edited. ${ }^{21}$

The four long sentences by Brentano, in line with Diderot's ekphrases in Les Salons, treat the space in the painting as a real space, into which one may immerse oneself. But unlike Diderot, the process in his case cannot succeed, for the claim (Anspruch) of the heart 
is broken by the rejection (Abbruch) of nature, and this breakage, as it were, is repeated in the painting.

It is magnificent to stand in infinite solitude on the seashore, beneath an overcast sky, and to look on an endless waste of water. Part of this feeling is the fact that one has made life's way there and yet must go back, that one would like to cross over but cannot, that one sees nothing to support life and yet senses the voice of life in the sigh of the waves, the murmur of the air, the passing clouds and the lonely cry of birds. Part of this feeling is a claim made by the heart and a rejection, if I may call it that, on the part of nature. But this is impossible in front of the picture, and what I should have found in the picture itself I found only between myself and the picture, namely a claim my heart made on the picture and the picture's rejection of me; and so I myself became the monk [Kapuziner], and the picture became the dune, but the sea itself, on which I should have looked out with longing - the sea was absent. ${ }^{22}$

This reconstruction of the reception to the painting is a metacriticism of it, but in a twofold sense it also refers to the essence of Friedrich's work. This essence is not the generality of longing and of the impossibility of longing, but the fact that with the figure inside the painting, Friedrich has created a second, internal spectator, who interacts with, perhaps even "identifies with" the external spectator. Brentano's identification with the "Kapuziner" was something new in the history of art, for previous identifications (donors, representative persons, the artist himself, self-portraits, etc.) had been objective in character. The identification of the internal and external spectator, ${ }^{23}$ by contrast, is emphatically subjective. What both spectators can see, the seascape, is actually not anywhere, because Friedrich, hesitating in these environs due to his reductions, observes - for the first time in the history of painting - nothing, in the positive sense of the word, that is, not the absence of something, but the opposite of being, as personified in the figure.

Let us see how Kleist carries on after Brentano. Firstly, in sharp contrast to Brentano's intonation ("It is magnificent to stand..."), the editor tragedises the above description, which sets life at the centre of the cyclorama of death: "There can be nothing sadder or more desolate in the world than this place: the only spark of life in the broad domain of death, the lonely centre in the lonely circle." ${ }^{24}$ Secondly, partly continuing the ironic, reportage-style section of the original Achim-Brentano text (later culled by editorial whim), in which the authors quoted the viewers' reflections, ${ }^{25}$ he strives to set the cultural context of the painting (Young, Kosegarten, etc.). He associates what he considers to be the apocalyptic effect of the painting with the fact that the foreground is pushed out of the frame. He formulates the immortal line, unfailingly cited ever since, which is so brutal that it presages the notorious scene of the eyeball being sliced with a razor in An Andalusian Dog: "[S]ince it has, in its uniformity and boundlessness, no foreground but the frame, it is as if one's eyelids had been cut off." ${ }^{26}$ In fact, though, apart from Kleist's wild nature, nothing stands behind this but a relatively simple metaphor: the eyelid is to the eye as the frame is to the picture. When the painter uses the frame not as a means of separation but brings it into play as a part of the composition (an innovation that Friedrich introduced in an earlier painting, the Tetschen Altar, which rustled up a storm of its own), then in a certain sense the frame ceases to be a frame, and is "cut off". That Friedrich refrained from painting an idealistic landscape is another novelty that Kleist recognises, contextualising it in terms of the contrast between North and South. Like many other visitors to the exhibition, Kleist also mentions Ossian. Based on this painting, any natural phenomenon at all could be taken up as subject matter: "a square mile of the sand of Mark Brandenburg could be represented with a barberry bush, on which a lone crow might sit preening itself". ${ }^{27} \mathrm{He}$ also acknowledges Friedrich's almost bashful insistence on mimetic realism (a bold undertaking with regard to this painting, which contains not a trace of it), although it was only in respect of the details, and not of the whole, that this was - or became - typical of Friedrich's œuvre. He concludes his catalogue of impressions with a variation on a popular trope from antiquity, concerning works of art that have the capacity to deceive wild animals:

Why, if the artist painted this landscape using its own chalk and its own water, I believe he would make the foxes and wolves weep: the most powerful praise, without doubt, that could be given to this kind of landscape painting. ${ }^{28}$

This is a most peculiar sentence. The idea that a landscapist could take an arid sandy plain as his subject and paint it using the landscape's own materials, may derive from the influence of cycloramas, in which the 
foregrounds would regularly have the two-dimensional images replaced with three-dimensional objects. ${ }^{29}$ And of course we, as people with hindsight, are bound to come up with associations of land art from a century and a half after the "Monk." In both cases, mimetic realism was radicalised to almost absurd lengths, which is diametrically opposed to Brentano's notion, in which mimesis is sure to fail. Before imagining, however, that the compliment may in some way be back-handed, intoning the traditionally low hierarchical position of the mimetic landscape, we must note that in his closing sentence, Kleist calls Friedrich's work a wonderful painting, and acknowledges his perturbation as a spectator.

Friedrich's seascape is stripped down to a vista composed of land, sea, sky and birds, with the solitary figure observing it all. One of the most noteworthy aspects of the painting is how extremely small this figure is. Among the copious reproductions of the work, it is rare to find the figure magnified. Upon closer inspection, however, an astonishing remnant of the uncertain process of development the painting went through is revealed, namely the anatomical anomaly whereby the feet of the figure, who has his back to us, are pointing almost completely in our direction. Busch explains this with the fact that in the original concept, the figure was turned halfway around. ${ }^{30}$ After the figure was subsequently altered so as to stare straight out to sea, the feet must have remained in the same position due to an oversight. This error, difficult to make out with the naked eye, and generally not mentioned in the literature on the "Monk", therefore captures the famous Rückenfigur, which became Friedrich's signature motif, in statu nascendi. The extreme significance of this artifice, which through overuse became tacky at times, or downright obnoxious in the case of the iconic work titled Wanderer above the Mists (Fig. 2), ${ }^{31}$ merits deeper consideration.

Rückenfiguren did not appear for the very first time in Friedrich's paintings, although the previous incidences could not really be described as precedents to Friedrich's figures in a historico-philological sense. ${ }^{32}$ My mentioning them here is solely to highlight their typological contrast. In the scenes of action, Giotto was the great master of backward-facing figures: in the Scrovegni Chapel splendid examples can be seen of figures conversing, slicing bread, or taking part in the Massacre of the Innocents. If we concentrate only on figures who are observing the view, then Jan van Eyck's innovation of 1435 - the little figures in the background of the Madonna of Chancellor Rolin, gaz- ing out through the gap in the crenellations at the city below and the nature beyond (Fig. 5) - was taken up shortly afterwards by Rogier van der Weyden, whose Saint Luke Drawing the Virgin has a background with a similar, albeit far less detailed composition. Rogier's work was copied several times over the following decades, and the same motif recurs in many other paintings for a further generation or two, including on the other side of the Alps, where Domenico Ghirlandaio incorporated it into his Visitation of 1485/90.33 A Rückenfigur of a different type, visible in the Death of the Virgin by Petrus Christus (1457/67, San Diego; Fig. 6), has been described as, "An apostle is leaning out of the opened double window in the rear wall of the room, lost in a reverie, like a figure by Caspar David Friedrich, staring at forest-covered hills." Later we can read:

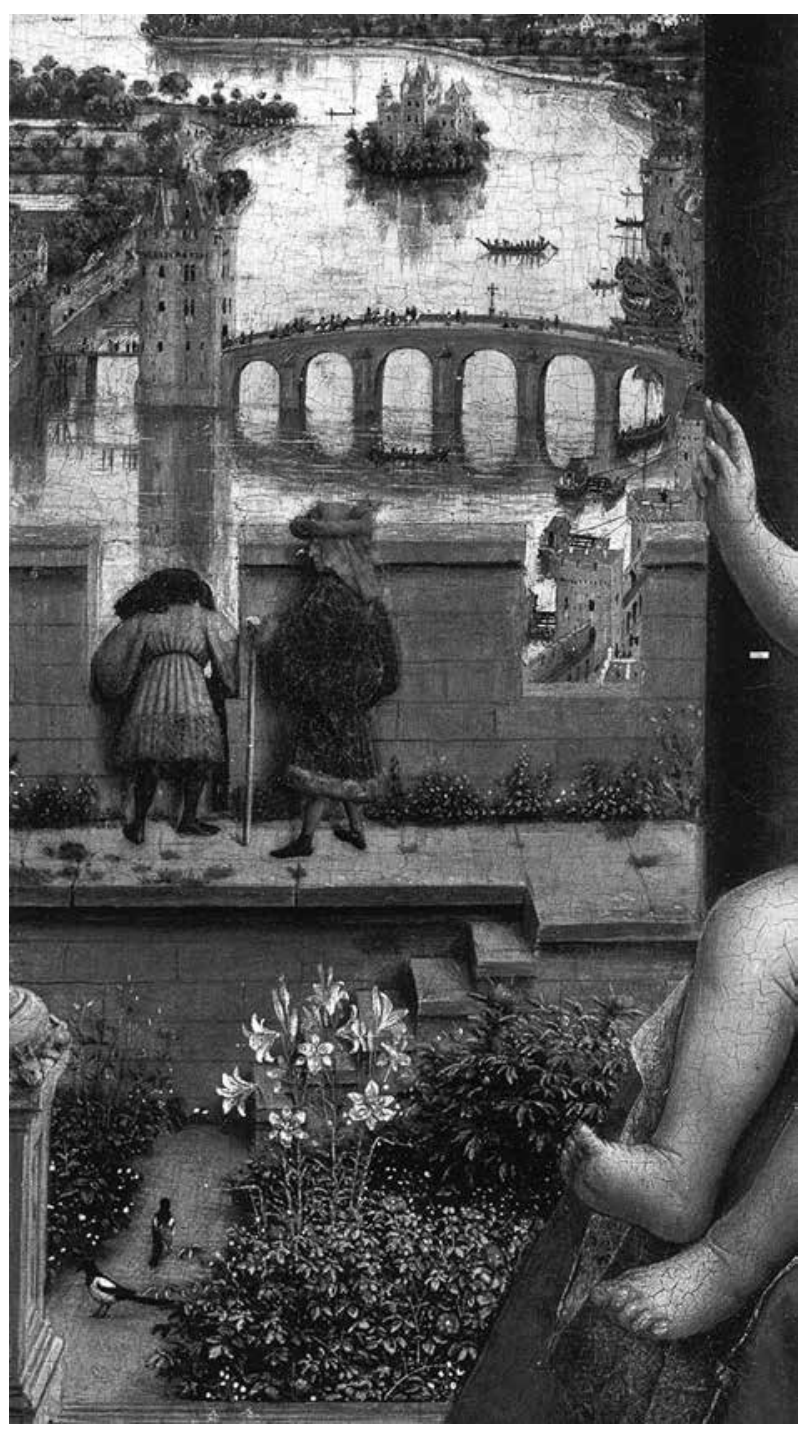

Fig. 5. Jan van Eyck: Madonna of Chancellor Rolin, c. 1435 , detail; Paris, Louvre 
The physiognomies of the apostle figures [...] wear their customary impassive expressions. The pre-romantic Rückenfigur, however, who turns away from everything and seeks solace by staring into the unpeopled wilderness, is a wonderful invention. ${ }^{34}$

The type of figure used by Jan van Eyck and Rogier van der Weyden is often referred to in the literature as an implicit spectator of the painting. Even the great Otto Pächt has defined the little men in the Van Eyck as "personifications of our visual experience" ("Personifikationen unseres Blickerlebens"), even though the actual spectator is seeing things from a much higher vantage point than the figures. ${ }^{35}$ I would tend to imagine that subjectively identifying the actual spectator with the spectator in the painting is something that developed only later, genuinely associable with Friedrich. The fifteenth-century type is rather a device to guide the spectator's eye beyond the initial spectacle, especially in the Rogier, where the male figure is pointing into the distance to direct his female companion's attention towards the scenery. In the more complex case of Jan van Eyck - in which the spectacle, in all its realistic detail, is also a vision - one of the figures is leaning over the low wall of the embrasure to take

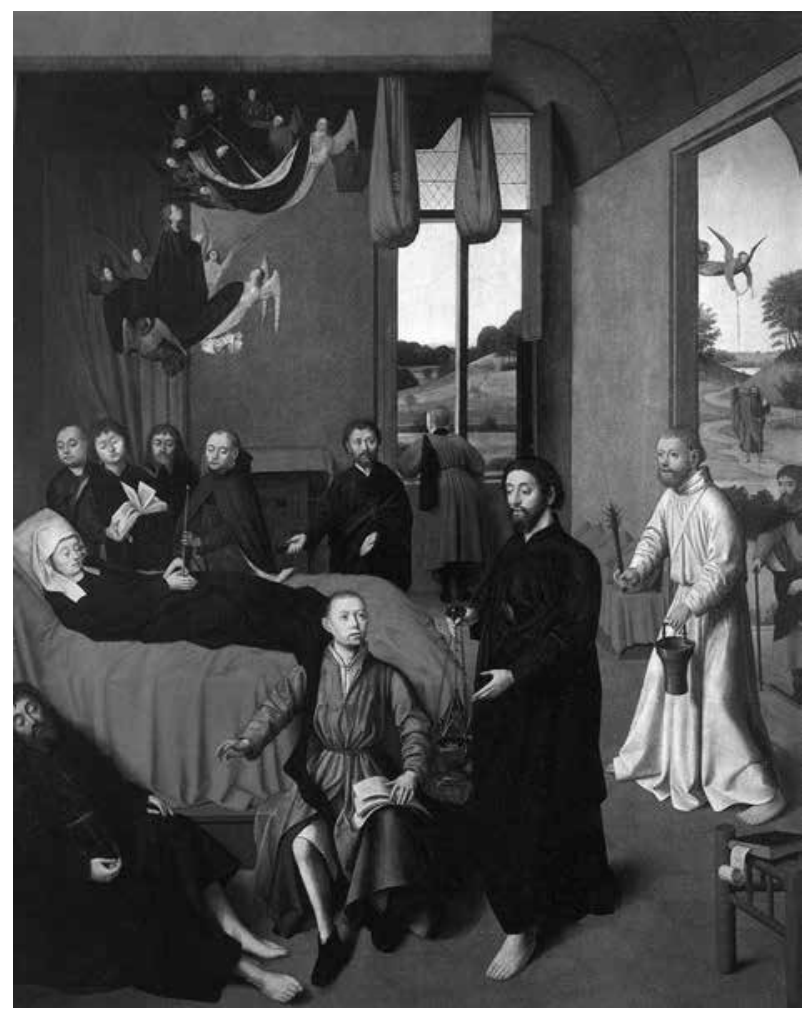

Fig. 6. Petrus Christus: Death of the Virgin, c. 1457-1467; San Diego (Cal.), Timken Museum of Art in the reflection of the spectacle as seen in the water below, while the other figure, dressed in a red turban and holding a cane - traditionally held to be the painter himself - explains something to him. In these instances, the view is presented as it is and not as a personal view; the spectacle - as shown by the size of the figures - cannot be compared with the spectator. This is why this little detail from the Van Eyck painting turns up in a miniature from a decade and a half later, representing the deadly sin of sloth (Fig. 7). ${ }^{36}$ Looking may become a symbol for acedia because it inheres the risk that the rich variety of the created world will divert the viewer away from its creator. There is a danger of conversio ad creaturam.

The little figures standing with their backs to us, like a couple of traffic police officers, distract our attention as spectators. Unlike in Friedrich's paintings centuries later, what we see in Van Eyck's work is not what the figures see, but the objective world as the background of Rolin's vision; not a landscape, but the world or the cosmos, of which everything is a part: the blue-tinted mountains in the distance, the cultivated hillsides, the river with its islands and the bridge linking the two banks, the two towns themselves (such fecund sources of iconographic speculation), and the teeming crowds of people, who are so incredibly tiny that we are left with the impression that, given a powerful magnifying glass, or even the microscope referred to by Panofsky, we could uncover ever closer details of the hustle and bustle of life. And zooming back out to the main scene of the painting, just as much attention is paid to the enclosed garden, the bas-reliefs on the columns, the text in Rolin's prayer book, the fabric on the garments worn by the Virgin and the chancellor, the pattern of the stone floor, the delicate working on the crown held by the angel, and so on. As Pächt most appositely expressed it, this is "the constitutive passivity of seeing" ("konstitutive Passivität des Sehens").

With the radical displacement of originality from representational material to vision, from the 'what' of representation to the 'how', it became irrelevant whether the raw material depicted was a piece of nature or a piece of art, for it was, in either case, painted reality. ${ }^{37}$

The many examples of the Rückenfigur painted by Caspar David Friedrich are a far cry from those observing the world in the works of Jan van Eyck and Rogier van der Weyden. They are different in both the "what" and the "how". In Friedrich's works the figures are the 


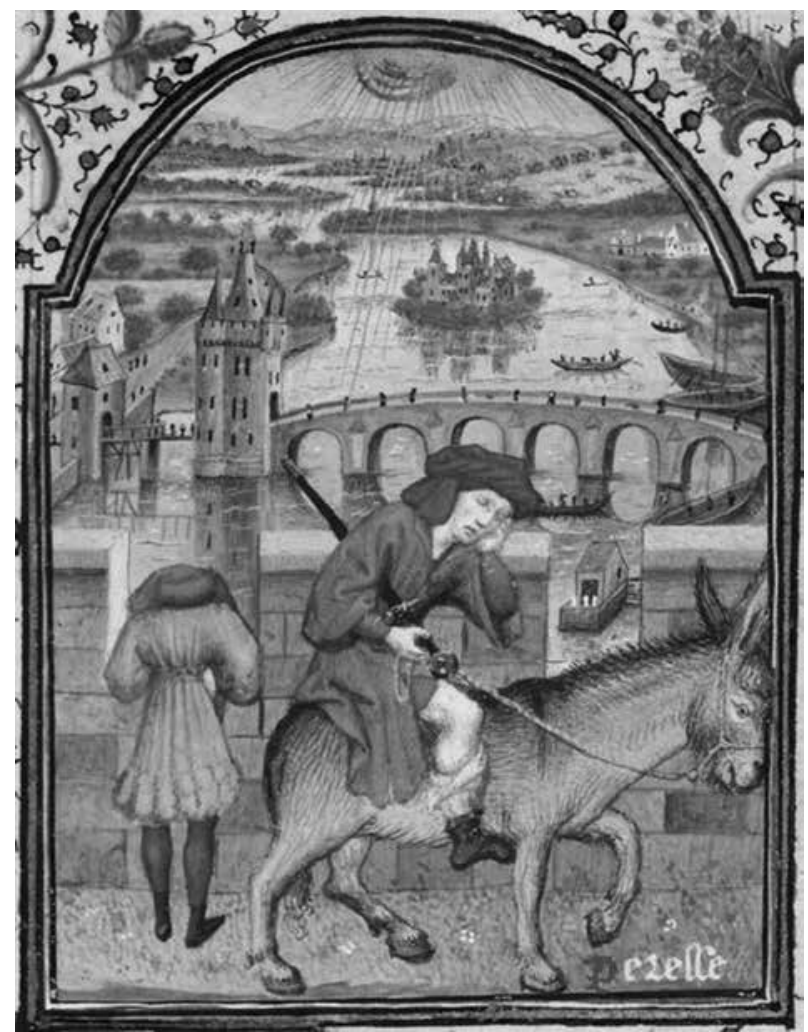

Fig. 7. Dunois Master (active between c. 1430 and c. 1465): Idleness, from the Dunois Hours, London, British Library

protagonists because we see what they see. ${ }^{38}$ And what we see through them is the now separate landscape, untouched by human hand, or at most, if the works of man are sometimes shown, then it is a ruin (on the way to becoming part of nature once more), a distant, almost unapproachable cross, far away from the inhabited world, the supernatural vision of a cathedral, or a complex of ecclesiastical buildings faintly espied on the horizon, like some extra-terrestrial destination. The unity of the created universe, which Jan van Eyck presents to us with such sublime detachment, striving to fill every iota of space with utmost verisimilitude, is replaced - in Friedrich - by the desire to empty the universe, so that even the viewer is incidental, and could just as well disappear; his unjustifiable hope is directed toward the faith-given promise of something beyond this world.

It does not wish to determine and explain the universe according to its nature as does metaphysics; it does not desire to continue the universe's development and perfect it by the power of freedom and the divine free choice of a human being as does morals. Religion's essence is neither thinking nor acting, but intuition and feeling. ${ }^{39}$
The religious meaning proffered by Friedrich is profoundly problematic, and this melancholic sense of foreboding permeates the majority of his works. It is this that often results in his paintings having an overwrought and contrived symbology.

Not so his seascape. Here, where his Rückenfigur first appears, ${ }^{40}$ the extreme reduction (which perhaps, in many respects, resulted in random effects) avoids the distinctive gesture of later figures of this kind, in which our view is guided from the close-up view of earth to the infinity of the distance. In this painting, even infinity perishes. Spatial depth is diminished.

Since the picture neither points out a way leading
from the foreground to the more distant spaces,
nor allows a sense of depth to be perceived by
gradually presenting motifs, such as trees or boats,
the effect of space remains extremely constrained.
The lack of measurable motifs also entails an
absence of perspectival lines with which to orien-
tate. In this way, not only does the planarity of the
painting dominate over the spatiality of the land-
scape; even more than this, there is nothing for the
beholder to cling to in order to determine one's
own position and perspective. ${ }^{41}$

The huge amount of reduction in this accidental masterpiece brought about such a radical abstraction that none of the century's landscapists, not even those who were more accomplished masters than Friedrich, would have attempted or even imagined. It was not until the "great abstraction" (as Kandinsky put it) of the early twentieth century, a hundred or so years after the historic and felicitous moment of its conception, that Friedrich's invention gained currency, for by then the notion of a self-destructive, anti-illusionistic landscape, which rejected objectivity and referentiality, had become far more digestible. By then, however, the figure had long since become superfluous to painting.

The diminutive size of Friedrich's Rückenfigur came about for different reasons from those responsible for the tininess of the backward-facing figures of the kind used by Jan van Eyck and Rogier van der Weyden. In the latter case, the secondary figures are so small only in relation to the Virgin and Child in the foreground. In Friedrich's case, the minuteness of the figure signifies the fragility of being. Turning the figure around from his original pose is a further reduction, for it lessens the subjective power of expression. All notion of monasticism and self-portraiture in this 
instance is mere anecdote compared with what we can see: a person vis à vis de rien. Its significance derives from the figure's dissociation from all emotion.

This is a surprising difference from the Rückenfiguren in Friedrich's later works, who are usually much larger and occupy far more of the picture. Naturally, these figures show no direct emotional expression either, but they are looking at something - the sea and a white sail in the distance, the moon, the moonrise, the mountains rising above the mist - which generates a sentimental atmosphere, into which the spectator is placed. Joseph Leo Koerner, author of an outstanding volume on Friedrich, in his interpretation of Carus, contrasted the objectivist staffage of a classical landscape (a practice still followed by numerous German artists during Friedrich's lifetime, from Philipp Hackert, a member of the preceding generation, to Joseph Anton Koch, who was just a few years older than Friedrich) against the Rückenfigur, which he refers to as the "halted traveller":
Where classical staffage aspires to humanize landscape, inscribing it into a plot and determining its value according to an artificial hierarchy of types, the halted traveller works to naturalize us as viewers, enabling us to enter more fully into the landscape $^{42}$

This important thought helps to underline the point that the Rückenfigur devised and deployed by Friedrich taught us, at the dawn of modern painting, that what we should see in a picture is not reality, but a way of seeing. However, the identification between the spectator of the painting and the spectator inside the painting, the possibility of which is raised here, comes about, in the case of the first Rückenfigur, not as a consequence of emotional identification, as in every later case, but within the complex relation between identification and the failure of identification, the most accurate description of which, unsurpassed to this day, was written by Brentano. The external spectator who

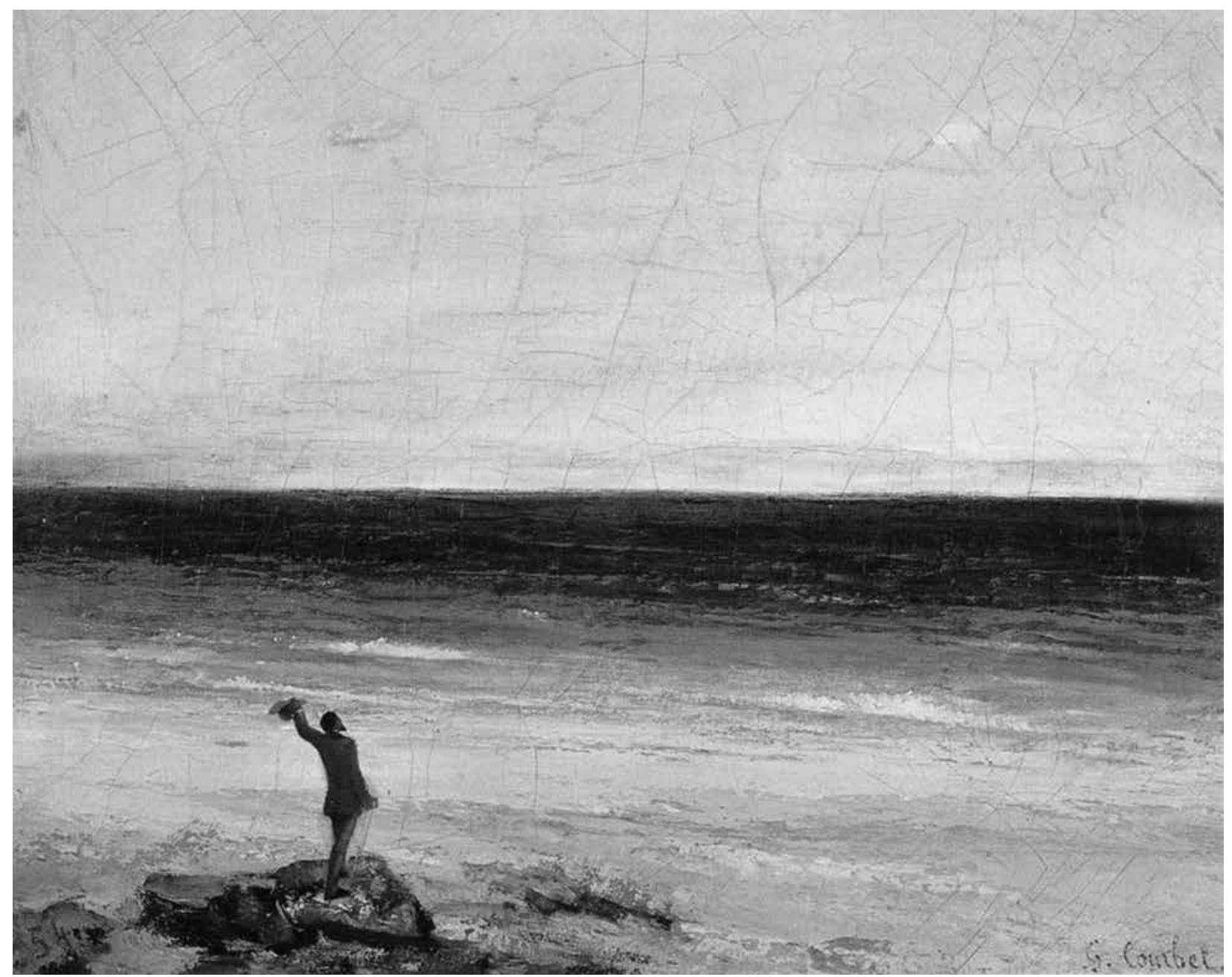

Fig. 8. Gustave Courbet: The Sea at Palavas, 1854; Montpellier, Musée Fabre 
looks at what the internal spectator is looking at, does not see anything, or more precisely, sees nothing.

Besides Friedrich's later Rückenfiguren, another clarificatory analogy, without any correspondence of influence, is provided by a few much later paintings by Gustave Courbet, who not only made use of the innovation of placing the horizon extremely low down and filling the larger part of the canvas with evocations of sky, but also opted for similarly small figures. Compared with Friedrich's figures, however, Courbet's are not dispassionate in the slightest. In the painting entitled The Sea at Palavas (1854; Fig. 8), which is sometimes mentioned in reference to Friedrich, Courbet (the self-portrait is rendered obvious by the halfprofile and pointed beard) waves his hat in greeting to the Mediterranean Sea, "as if in an exalted exchange between physical equals", as Michael Fried wrote. ${ }^{43}$ In contrast to the harmony with nature that holds sway in this painting, La Trombe of 1867 evokes a sense of vulnerability in the face of nature: a tiny female figure standing on a rock before an impending curtain of rain raises both her hands in panic or desperation. In this painting, the sense of depth is clearly conveyed by the sailing boats imperilled by the coming storm.

Nothing of this kind can be discerned in Friedrich's "Monk". Brentano's description, without making up a story of any kind, is amazingly prosaic in stating that the figure had to make his way to the point where he stands, and he will have to make his way back again. This is an assertion, made in the same tone as that of the picture, that the figure is "outside" in nature. However small he may be, it is his presence that turns nothingness into landscape, while the minimalised spatial depth and the non-existence of infinite experience that results from this, as well as the relativisation of the three elements of earth, water and air - especially the latter two - all sustain the non-nature of the landscape created by the human eye. Brentano's description loses its way when he looks for unfulfillable longing in this situation. The nothingness faced by the figure is not negative, not absence and not negation: it is impossible to wish for it to be fulfilled, and therefore neither the internal nor the external spectator can have any sense of infinite longing towards it.
It is also apparent, however, that without the tiny, infinitely fragile figure, not only would the enormous bluish grey and murky brown patches of the painting not come together as a landscape, but nothingness - the alternative name for these patches - would also not be there. This sense of nothing can appear in barren nature, because it arises out of its relationship to humans, as the opposite of being.

If our train of thought is correct, then only once in his career, and without any conscious intention at all, did Friedrich succeed in producing a painting which, for the first time in the history of the genre, took account of the presence of nothing as a boundary condition of human life. ${ }^{44}$ To arrive here, he had to lead his man out of the hubbub of everyday life into nature, into the landscape, from which he had to eliminate all other trace of human activity, and which he even had to change into a "counter-landscape." The minimalism in the painting, unparalleled in its age, rebuffs as groundless over-explications such basic types of interpretation as Brentano's longing, Kleist's doubt, Friedrich's faithful humility or the majesty of a human blade of grass. The creator himself is an interpreter of his own works, but not necessarily the most authentic one. Still, the fact that Friedrich did not comprehend what he had done is demonstrated by the advantages of this. His conceptual message - since there is none, for he clearly did not "know" what he had wrought - is not aggressive here, as it so often is in his ceuvre. The ground on which the figure stands, and the sea and sky in front of him, are all present, and this presence transitions into nothingness. This was what proved to be the suitable artistic solution for distinguishing between the negative nothing and the positive nothing.

What is expressed by the "Monk", and by the painting as a whole, is the anxiety that arises when being and nothing meet. Anxiety is not fear, not despondency, not exasperation, and it has no subject (or its subject is nothingness). The image of anxiety presented in The Monk by the Sea preceded its own conception, with its philosophical career only commencing more than three decades later in the mind of Kierkegaard.

\section{NOTES}

\footnotetext{
${ }^{1}$ Plato, Ion, translated by Benjamin Jowett. http://classics.mit.edu/Plato/ion.html

2 "Poets are the hierophants of an unapprehended inspiration; the mirrors of the gigantic shadows which futurity
}

casts upon the present; the words which express what they understand not; the trumpets which sing to battle, and feel not what they inspire; the influence which is moved not, but moves." Percy Bysshe Shelley, A Defence of Poetry=English 
Essays: Sidney to Macaulay. The Harvard Classics. 1909-14. http://www.bartleby.com/27/23.html

${ }^{3}$ The most widely known title is Der Mönch am Meer. An alternative title is given in the catalogue of Friedrich's works: Wanderer am Gestade des Meeres (Wanderer on the Seashore). cf. Helmut Börsch-Supan \& Karl Wilhelm Jähnig, Caspar David Friedrich. Gemälde, Druckgraphik und bildmäßige Zeichnungen. München: Prestel, 1973. 302 ff. (cat. no. 168).

${ }^{4}$ William Vaughan, "Caspar David Friedrich" = William Vaughan, Helmut Börsch-Supan, Hans Joachim Neidhardt, Caspar David Friedrich. 1774-1840. Romantic Landscape Painting in Dresden. London: The Tate Gallery, 1972, 30.

${ }^{5}$ Ibid.

${ }^{6}$ The title is difficult to translate because the Große Gehege, or Große Ostra-Gehege, is the traditional historical name of the location (now part of the municipality of Dresden), whose meaning (Gehege = enclosed hunting ground; Ostra $=$ former village beside Dresden) has no connection to the image in the painting. The title is therefore frequently changed to The Large Enclosure, La grande riserva, La Grande Réserve.

${ }^{7}$ cf. Werner Busch, Caspar David Friedrich. Ästhetik und Religion. München: Beck, 2003.

${ }^{8}$ cf. Werner Busch, "Friedrichs Bildverständnis" = Caspar David Friedrich. Die Erfindung der Romantik. Museum Folkwang Essen - Hamburger Kunsthalle. München: Hirmer 2006, 46

${ }^{9} \mathrm{cf}$. list of pictures and explanations in the catalogue raisonné. Börsch-Supan \& Karl Wilhelm Jähnig, Caspar David Friedrich, loc. cit. 224-231.

${ }^{10}$ Werner Busch, "Friedrichs Bildverständnis", loc. cit. 33.

${ }^{11}$ A sepia drawing titled Summer (1803), part of a series on the seasons, which he later turned into a painting (1807/8, now in Munich), not only features two intertwining trees in the style of Claude, but also a loving couple, a direct reference to the lovers in the Dresden Acis and Galatea. This would have been so apparent to every viewer in Dresden at the time as to be quite astonishing, as first pointed out by Vaughan in 1972: cf. William Vaughan, "Caspar David Friedrich", loc. cit. 27. A more recent interesting discovery is that a pen-and-ink drawing of 1810 titled Riverside Landscape with Arched Bridge in the Goethe Museum in Frankfurt is a precise, albeit abstracted reproduction of another work by Claude, also in Dresden: Landscape with the Flight into Egypt. Cf. Petra Maisak, "Caspar David Friedrich und Claude Lorrain. $\mathrm{Zu}$ einer Briefsendung an Amalie von Beulwitz in Rudolstadt um 1810" = Pantheon 48, 1990, 123-129. Friedrich often composed paintings as pendant pairs (the pendant of The Monk by the Sea is The Abbey in the Oakwood), a practice first established by Claude.

12 See: Sándor Radnóti, "An Old Man on the Sea Shore" = Acta Historiae Artium, 58, 2017, 115-125.

${ }^{13}$ cf. Kristina Mösl und Philipp Demandt (eds.), Der Mönch ist zurück. Die Restaurierung von Caspar David Friedrichs Mönch am Meer und Abtei im Eichwald. Berlin: Nationalgalerie, 2016.

${ }^{14} \mathrm{cf}$. Werner Busch, Caspar David Friedrich. Ästhetik und Religion. loc. cit. 49-58.

${ }^{15}$ Published by Börsch-Supan in his study titled "Berlin 1810. Bildende Kunst" in the 1987 Kleist-Jahrbuch. Berlin: Erich Schmidt Verlag, 1987, 74 ff. The later publication $=$ Caspar David Friedrich, Die Briefe. Hrsg. u. komm. v. Herrmann Zschoche. Hamburg: ConferencePoint Verlag, 2006, 219.

${ }^{16}$ Christian August Semler (1767-1825), for instance, refers to a bald old man dressed in brown. cf. "Ueber einige Landschaften des Malers Friedrich in Dresden. Dresden im Februar 1809.", 233-238. = Journal des Luxus und der Moden. April 1809, 234

${ }^{17}$ Heinrich von Kleist [Clemens Brentano], "Empfindungen vor Friedrichs Seelandschaft" (Sentiments before Friedrich's Seascape). To be precise, this identification stems from Brentano, for Kleist's text commences from the subsequent sentence.

${ }^{18}$ cf. Börsch-Supan \& Karl Wilhelm Jähnig, Caspar David Friedrich. loc. cit. 304 ff. cat. no. 169

${ }^{19} \mathrm{cf}$. Werner Busch, Caspar David Friedrich. Ästhetik und Religion. loc. cit. 65.

20 See note 15 .

${ }^{21}$ cf. Christian Begemann, "Brentano und Kleist vor Friedrichs Mönch am Meer. Aspekte eines Umbruchs" = Deutsche Vierteljahrsschrift für Literaturwissenschaft und Geistesgeschichte. 1990 64/1, 54-95.

22 Kleist-[Brentano], "Sentiments before Friedrich's Seascape". https://artinfiction.wordpress.com/2013/07/11/ heinrich-von-kleist-clemens-bretano-achim-von-arnimvarious-expressions-experienced-before-a-seascape-with-amonk-by-caspar-david-friedrich-1810/

${ }^{23}$ This distinction, in analytical philosophy was described by Richard Wollheim in chapter III of Painting as an Art "The spectator in the picture: Friedrich, Manet, Hals". London: Thames and Hudson, 1987, 101-186.

${ }^{24}$ Kleist-[Brentano], "Sentiments before Friedrich's Seascape".

${ }^{25}$ cf. Clemens Brentano / Achim von Arnim, "Verschiedene Empfindungen vor einer Seelandschaft von Friedrich, worauf ein Kapuziner. (Bei einer Kunstausstellung.)" = Iris. Unterhaltungsblatt für Freunde des Schönen und Nützlichen. Nr. 20, 28. 1. 1826, 77 ff. Kommentierte digitale Edition von Jochen A. Bär. Vechta 2014. (Quellen zur Literatur und Kunstreflexion des 18. und 19. Jahrhunderts, Reihe A, Nr. 1645.) http://www.zbk-online.de/texte/A1645.htm

${ }^{26}$ Kleist-[Brentano], "Sentiments before Friedrich's Seascape".

27 Ibid.

${ }^{28}$ Ibid.

${ }^{29}$ cf. Werner Hofmann, Caspar David Friedrich. Naturwirklichkeit und Kunstwahrheit. München: C. H. Beck, 2005 [2000], 57. Likewise, Kleist is referring to a cyclorama when he sees the figure in the picture at the centre of a circle. cf. Christian Begemann, "Brentano und Kleist vor Friedrichs Mönch am Meer", loc. cit. $85 \mathrm{ff}$.

${ }^{30} \mathrm{cf}$. Werner Busch, Caspar David Friedrich. loc. cit. 61

31 The noted scholar Carl Gustav Carus, who was friends with Friedrich for over a decade (1817-1829), remained his epigone as a painter for the rest of his life. His painting of 1818 titled Wanderer on the Mountain Peak was an involuntary parody of Friedrich's earlier Wanderer above the Mists (Fig. 2). His work of 1839, titled, in itself slightly parodistically, Raphael and Michelangelo at Full Moon, Gazing at Saint Peter's Basilica, was an attempt to transpose the idea of the Rückenfigur into the genre of history painting. cf. Gerd Spitzer \& Petra Kuhlmann-Hodick, "Carus und Caspar David Friedrich" = Carl Gustav Carus: Natur und Idee. Katalog 
Staatliche Kunstsammlungen Dresden, Staatliche Museen zu Berlin, Deutscher Kunstverlag, 2009, 345-351.

32 Friedrich's use of the Rückenfigur may have something to do with the fact that, like Claude Lorrain, he did not excel at portraying figures in motion, nor either - apart from a few outstanding self-portrait drawings - at evoking facial features.

33 See, for example, La Crucifixion du Parlement de Paris (Louvre, c. 1452), and the painting in Liège by the Master of the View of Saint Gudula (Madonna and Child with Donor and Mary Magdalene, c. 1475). For Ghirlandaio cf. Paula Nuttall, From Flanders to Florence, the Impact of Netherlandish Painting; 1400 - 1500, New Haven and London: Yale University Press, 2004, 140 and 282.

${ }^{34}$ Hans Belting \& Christiane Kruse, Die Erfindung des Gemäldes: Das erste Jahrhundert der niederländischen Malerei. München: Hirmer, 1994, 203. (Ch. Kruse.)

35 Otto Pächt, Van Eyck, die Begründer der altniederländischen Malerei, München: Prestel, 1989, 86.

36 cf. Felix Thürlemann, "Schauen als Faulheit. Eine gemalte Kritik an der Weltsicht Jan van Eycks"=Christiane Kruse \& Felix Thürlemann (eds.), Porträt - Landschaft - Interieur. Jan van Eycks Rolin-Madonna im ästhetischen Kontext, Tübingen 1999, 187-199. The picture, one of the illustrations of The Dunois Hours, shows a Van-Eyckian landscape. The Rückenfigur looking out through the battlements is still there, in the same distinctive red turban, but the other figure, instead of a cane, has a sword tucked beneath his arm, while he sleeps on the back of a donkey - the allegorical creature for acedia.

37 Otto Pächt, Van Eyck..., loc. cit. 209.

38 "The Rückenfigur is so prominent in the composition that the world appears to be an emanation from his gaze, or more precisely, from his heart." Joseph Leo Koerner, Caspar David Friedrich and the Subject of Landscape. London: Reaktion Books 2009² [1990], 213.

${ }^{39}$ English translation by Richard Crouter. Friedrich Schleiermacher, "Reden über die Religion" = Schleiermacher, Theologische Schriften. Berlin: Union, 1983, 78. Schleiermacher's direct influence on Friedrich has been surmised by many (as the two men knew each other), and proving this was one of Werner Busch's main aims in his book on the artist. I mention him not in this regard, but as one of the greatest thinkers, alongside Kierkegaard, on the problems of religion, who concluded that religion should withdraw from the territory of the pure mind and the practical mind, that is, from speculation (metaphysics) and practice (morals), and occupy a third field beside them, as their supplement and counterpart. "Practice is art, speculation is science, religion is sense and taste for the Infinite." [Praxis ist Kunst, Spekulation ist Wissenschaft, Religion ist Sinn und Geschmack fürs Unendliche."] "Reden...", loc. cit. 79.

${ }^{40}$ A figure standing with his back to the viewer had previously appeared only once in his œuvre, in a small $(12 \times 18 \mathrm{~cm})$ sepia drawing titled Landscape at Sunrise (Weimar, c. 1804/5). In the Börsch-Supan catalogue it is no. 121, and the autograph copy is no. 123. It shows a peasant or a shepherd with a rod and a dog, watching the sunrise. In proportions, he is hardly any larger than the "monk". The figure, however, is staffage, whereas the novelty in Friedrich's landscapes with a Rückenfigur (none of his later figures were ever so small) was that he broke with the staffage figures of landscape tradition; they are incomparably more significant and loaded with meaning. The oil painting titled Moonlight on the Seashore (private collection, Berlin), which features four sailing ships and two hat-wearing fisherman standing with their backs to us, was dated to 1807 in a 1938 book by Herbert von Einem, although later research has regarded the work, together with a group of other paintings, as originating at least a decade later. cf. Herbert von Einem, Caspar David Friedrich. Berlin: Rembrandt Verlag, 1938, 19; Werner Sumowsky, Caspar David Friedrich-Studien. Wiesbaden: Franz Steiner Verlag, 1970, 121 ff. See the Börsch-Supan catalogue, titled Moonlit Night on the Seashore with Fishermen, cat. no. 240.

${ }^{41}$ Johannes Grave, Caspar David Friedrich. München: Prestel, 2012, 159.

42 Koerner, Caspar David Friedrich and the Subject of Landscape, loc. cit. 245.

${ }^{43}$ Michael Fried, Courbet's Realism. Chicago: The University of Chicago Press, 1990, 261. Interestingly, Whistler painted Courbet on the seashore as a kind of homage to Courbet's composition (Harmony in Blue and Silver: Trouville, 1865). For Courbet's painting, see also: Ségolène Le Men, Courbet. Paris: Citadelles \& Mazenod, 2007, 305; and the commentary by Michel Hilaire=Catalogue. Gustave Courbet, Metropolitan Museum of Art, New York, 27 February - 18 May 2008, 272 ff.

${ }^{44}$ The Black Paintings that Goya produced at the Quinta del Sordo (House of the Deaf Man) ten years later, towards the end of his life, especially the canvas titled The Dog, could - despite the complete absence of philological connection be understood within a similar frame of reference, but the Friedrich work should not be "interpreted out of [the] context" of Goya's œuvre, an incomparably greater master than the German painter. 